
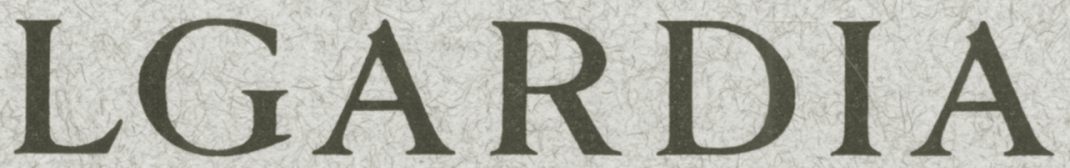

A Journal of Agricultural Science Published by the California Agricultural Experiment Station

\title{
PATHOLOGICAL ANATOMY OF
}

CARROT ROOT SCAB AND SOME FACTORS AFFECTING ITS INCIDENCE AND SEVERITY

R. G. GROGAN, F. W. ZINK, AND K. A. KIMBLE 


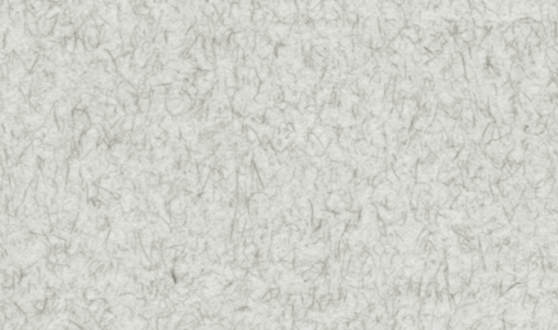

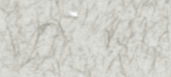




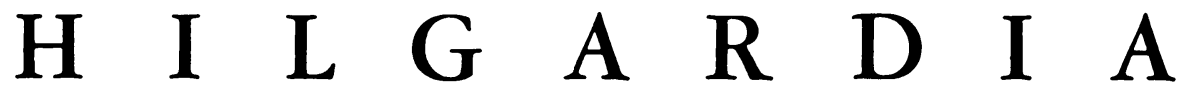

A Journal of Agricultural Science Published by

the California Agricultural Experiment Station

VOI. 31

JUNE, 1961

No. 3

\section{PATHOLOGICAL ANATOMY OF CARROT ROOT SCAB AND SOME FACTORS AFFECTING ITS INCIDENCE AND SEVERITY ${ }^{1}$}

\author{
R. G. GROGAN, ${ }^{2}$ F. W. ZINK, ${ }^{3}$ and K. A. KIMBLE ${ }^{4}$
}

\section{INTRODUCTION}

RоOT SCAB of carrot has been a serious disease in California since at least 1937 , when it was first observed in the state by Ark and Gardner $(1942 ; 1944)^{5}$ in the Santa Maria Valley. They described the disease and reported the cause to be direct root infection by Xanthomonas carotae (Kendrick) Bergey et al. originally described by Kendrick (1934), as the cause of a blight of the leaves and umbels of seed carrots. A similar disorder was reported by Ramsey (1937) and Ramsey and Wiant (1941) as occurring on California carrot roots shipped to the Chicago market. They isolated Fusarium spp. from the lesions, and concluded that the disease was caused by Fusarium.

From experimentation and observations the present paper evaluates the effect of several factors on the prevalence and severity of the disease and describes its pathological anatomy.

\section{THE DISEASE}

\section{Distribution in California}

Carrot root scab in California occurs commonly in the Salinas Valley, from Chualar south to King City, and in the Lompoc and Santa Maria valleys. In 1955 it also occurred in a late fall crop near Patterson, but did not recur there the following year. The disease has not been observed in the carrot-growing areas of the lower Salinas Valley, near the Pacific Ocean, although as many as 18 carrot crops in twenty years have been grown in some fields there.

\footnotetext{
${ }^{1}$ Submitted for publication October 17, 1960.

${ }^{2}$ Professor of Plant Pathology and Plant Pathologist, Experiment Station, Davis.

${ }^{3}$ Specialist in the Experiment Station, Department of Vegetable Crops, E. Alisal Branch, Salinas.

4 Laboratory Technician IV, Department of Plant Pathology, Experiment Station, Davis.

"See "Literature Cited" for citations referred to in the text by author and date.
} 


\section{Outside California}

During recent years a similar, if not identical, disorder has caused losses in carrots near Grants, New Mexico (Leyendecker and Nakayama, 1957). A sample of such scabby roots (provided by Dr. P. J. Leyendecker in 1955) resembled roots affected by the California disease. Chester W. Whitelaw, of Beryl, Utah, has described a root scab of carrot in Utah (personal communication). It differs somewhat from the California disease in that the blemishes consist entirely of dark rings extending from the root scars, without punctate eruptions. L. L. Stubbs (personal communication) has described a root scab of carrots that occurs sporadically in Victoria, Australia. Whether it is the same as the disease reported on herein is not known.

\section{Normal Developmental Anatomy of the Carrot Root}

The normal developmental anatomy of the young carrot root has been thoroughly described and illustrated by Esau (1940). A study of her work contributes much to understanding the abnormal anatomy of scabby roots. The normal developmental anatomy is briefly as follows:

In a primary state the carrot root has a diarch xylem plate with patches of primary phloem on opposite sides. Oil ducts are present in the pericycle; the two centralized ducts are located opposite the poles of the xylem plate, and there are several other ducts distributed in an are extending on both sides of the central ducts. No ducts are present in the pericyclic area opposite the primary phloem.

A cambium layer develops in a circle extending between the primary xylem and phloem. Secondary xylem and phloem produced by the cambium increase the girth of the root, rupturing and shedding the cortex. Cells of the pericycle divide actively, externally and internally to the oil ducts, giving rise to several layers of parenchyma. Parenchyma cells outside the oil ducts give rise to a phellogen that produces a corky periderm after the cortex sloughs. Some of the pericyclic cells just under the phellogen divide to produce oil ducts very close to the surface of the root and extending both vertically and horizontally to form an interconnecting network. The mature carrot root, therefore, is covered by a thin outer layer consisting of periderm and pericycle with oil ducts, and the bulk of the mature fleshy root (hypocotyl and taproot) is composed of highly parenchymatous secondary vascular tissues.

\section{Symptoms and Pathological Anatomy}

Scab lesions may occur at any point on the surface of the root. Young incipient lesions usually appear slightly sunken and greasy; the outer periderm cells are collapsed, often with brown necrotic spots in the centers. This type of lesion was illustrated by Ark and Gardner (1944) in their figure 2B. Cross sections through lesions of this type indicate that they are caused by rupture of oil ducts (fig. 2A, B). These lesions are of recent origin; overgrowth has not occurred and their surfaces are covered with material that stains heavily with Safronin-O in an iron-hematoxylin-safranin combination staining schedule. Common occurrence in the oil ducts of a substance with similar affinity for safranin, and continuous lines of the red-staining material between the ducts and the surface of lesions indicate that the material was 
exuded from the ducts. Its affinity for Sudan IV stain in fresh sections indicates that a major component is oil or fatty materials. Older lesions are quite variable in size, shape, and color. Some are black, brown, or reddish brown; occasionally they are sunken craters but more commonly are raised above the surface of the root. Young raised lesions are often covered with a mound of grayish-white material of cheese-like consistency. When this material was removed by washing in a strong stream of water, more was usually exuded within a few minutes. When thin free-hand sections of lesions covered with this material were floated in water in Petri plates and observed periodically for several days, the white material retained its original size and shape. Microscopic examination and dilution cultures revealed some bacteria present, but the material was composed mainly of small round particles of plant origin. An electron photomicrograph of particles of this material is presented in figure $3 \mathrm{C}$.

Some lesions are comparatively large and distinctly raised above the surface of the periderm. Lesions of this type are commonly encircled by a white border (fig. 1A). Cross sections through several of them (fig. 2F, G, H) reveal that they are comparatively deep-seated. Beneath some of them were extensive cavities partially filled with wound-healing cells (fig. $2 \mathrm{~F}$ ). Others appeared to have originated as cavities, but wound healing and other cell proliferation had occluded the cavities and raised the periderm above the root surface (fig. $2 \mathrm{H}$ ). The section illustrated in figure $2 \mathrm{~F}$ was of particular interest because the partially filled cavity was connected with an enlarged oil duct.

Some lesions occur in root scars and may extend completely around the root (fig. 1B). Such a lesion is referred to herein as "ring-scab," and the raisedpustular lesion as "punctate scab." In some instances the root is constricted, but the periderm is unbroken. More commonly, however, the periderm is broken to form ring-scab lesions in the constrictions. Associated with these constrictions is a disruption of the phloem and cambium tissues, resulting in extensive internal cavities (fig. 3B). It appears likely that the constrictions result from an injury of the cambium that prevents normal expansion of the root circumference by suspending production of secondary phloem and xylem. The phloem and cambium tissue can be disrupted when the root is quite voung, in which case the root may become severely constricted, as illustrated in Ark and Gardner's figure 1F (1944).

Another interesting phenomenon is the arrangement of punctate scab lesions in two definite lengthwise rows on opposite sides of the root (fig. 1C). In some instances, though no raised scab lesions are present, the lines are evident because of minute rifts in the periderm surface (fig. 1D). The line of punctate scab lesions, and also the line illustrated in figure 1D, occur where the primary phloem was pushed out by secondary growth. Esau (1940) described this area as follows: "Outside the primary phloem, where no oil ducts are present, secondary growth in the pericycle is less vigorous than elsewhere. The divisions begin here later than in the cells connected with the oil ducts and are less numerous. As a result of this comparatively sluggish growth, the surface of the rather young fleshy organ shows shallow grooves on the sides along the primary phloem strands." In most roots the shallow grooves are largely obliterated by secondary growth, but in some mature roots they remain evident. The periderm in this area is somewhat thinner and more sub- 
ject to rifting than on the remainder of the root, which accounts for the formation of such lines as in figure 1D.

The formation of punctate scab lesions along this line, however, appears to have another explanation. Examination of serial sections of several of these lesions indicated that the situation illustrated in figure 2C, D, E is typical of lesions formed along the line. In figure $2 \mathrm{C}$, which is a cross section through the edge of the lesion, there is a distinct and fully open oil duct; in figure $2 \mathrm{D}$, which is a cross section $30 \mu$ toward the center of the lesion from figure $2 \mathrm{C}$, the oil duct is much smaller and appears to have a cross wall through its center; in figure $2 \mathrm{E}$ the oil duct is completely occluded by small cells. Proliferation of cells in the lesion extends upward from the level of the oil duct, and the surface of the lesion is covered with a deeply red-stained substance that is commonly present in oil ducts. Figure 2I illustrates another lesion that was located among others on a line outside the primary phloem. In this lesion, oilinfused tissue near the surface of the root has been pushed up and sloughed by cell proliferation beneath the lesions. The lowest level of proliferated cells is just above a definite oil duct that was evident in serial sections at the edge of the lesion. It therefore appears that such lesions result from cell proliferation stimulated by substances in the oil ducts. The greater frequency of lesions along the line is probably due to the termination of oil ducts in this area, resulting in extrusion of the contents of the ducts into the tissue.

The type of lesion illustrated in figure $1 \mathrm{~F}$ occurs less often than the types described above, but is common enough to be found with little difficulty in fields where scab is prevalent. It consists of raised blisters, with the periderm covering either intact or broken. If broken, the tissue around the lesion becomes soaked with oil, which, on drying, becomes yellow or may become mixed with soil to form sticky encrustations. The blisters may occur separately, as in figure $1 \mathrm{H}$, or more or less united in irregular lines, as in figure 1G. Cross sections through these structures (fig. 1I) reveal that they are abnormally enlarged oil ducts, sometimes partially occluded with overgrowth cells.

It seems likely that this type of abnormality is due to the reaction of plants of certain genetic constitution to an environment favoring the production and accumulation of abnormal amounts of carrot oil (Grogan and Kendrick, Sr., 1952). Another abnormality observed repeatedly in areas where scab occurs is illustrated in figure $3 \mathrm{~A}$. The roots of young carrots have a blotchy, yellowish-white appearance instead of the even yellow of normal roots. The abnormality is more intense on the upper two thirds of the roots. Cross sections of such roots (fig. 3A) show severe rifting of the phloem tissue adjacent to the cambium, with almost complete separation of the pericycle-periderm tissues from the outermost phloem tissue. Usually there is no necrosis and the space between the outermost phloem and the pericycle becomes filled with woundhealing cells by harvest time.

In figure $3 \mathrm{~A}$ the periderm-pericycle tissue is connected with the outermost phloem at four points, but observations of serial sections revealed that the connections were consistent at only two points (indicated by $\mathrm{X}$ ), on opposite sides of the root, where the primary phloem has been pushed out by secondary growth. (This is the line on which punctate scab lesions form in a row, fig. 1C). The cause of this abnormality is not known, nor is its relationship, if any, to the development of scab. 


\section{Cultures and Inoculations of Organisms from Scab Lesions}

Cultures have often been made from carrot scab lesions, using various media and methods of surface sterilization. Bacteria are commonly associated with the lesions. The most common type has a spreading white growth, the second most common is bluish green, and the third is a creamy yellow. Representatives of all three types of bacteria have been mixed with steam-sterilized soil in which carrots were planted and allowed to grow for as long as five months, but in no instance has the amount or severity of scab been greater than in the uninoculated controls in which some lesions also occurred. Supposedly authentic cultures of Xanthomonas carotae, obtained from several sources, have been used to inoculate soil in which carrots were grown, but the incidence and severity of scab were not increased in comparison with uninoculated controls. It appears, therefore, that the bacteria commonly associated with carrot root scab are only secondary invaders, and not responsible for its development.

Fungi commonly associated with carrot scab lesions are: Fusarium oxysporum, Rhizoctonia solani, Stemphylium consortiale, Stemphylium botryosum, Stemphylium radicinum, Phythium spp., and Phytophthora spp.

Carrots grown in soil inoculated with $S$. radicinum have shown severe root damage (Grogan and Snyder, 1952). This organism can cause stubbing of roots, damping-off and death of seedlings, a black discoloration of root scars, a punctate black spotting somewhat similar to punctate scab, and large black rotted areas that usually start in wounds. S. radicinum is common in California carrot soils. Its effect is most evident near the crown, where it blackens the bases of the petioles.

Both Pythium and Phytophthora spp. are capable of causing root stubbing, damping-off, and discoloration of the root scars, especially if the infested soil is wet and cold.

The other fungi frequently isolated from scab lesions-Fusarium oxysporum, Rhizoctonia solani, Stemphylium consortiale, and Stemphylium botryosum - caused no apparent damage when used as inocula in steam-sterilized soils where carrots were grown. Other fungi are occasionally present in scab lesions, but carrot roots were not damaged in inoculation tests of the following: Pullularia spp., Phoma spp., Fusarium roseum, Fusarium moniliforme, and Penicillium spp. These fungi appear to be secondary invaders of the damaged tissue of scab lesions, and not involved in causing the disease.

A fairly high percentage of tissue pieces from scab lesions plated on nutrient media has been sterile, indicating that at least some of the lesions are caused not by a pathogen, but by abnormal host physiology and anatomy. This assumption is strongly supported by the fact that scab lesions have developed on carrot roots grown from heat- and mercuric-chloride-treated seed in steam-sterilized soil in the greenhouse-treatments that would have eliminated most, if not all, pathogenic organisms.

\section{Effect of Planting Date}

Field observations and a study of growers' records indicate that the earliest carrot plantings (seeded during December, January, February or March) are much more likely to develop serious root scab than are plantings after 
April 15. For example, scab records for 1950-1955 were as follows: scab at harvest was moderate to severe in 27 of 48 fields ( 56 per cent) planted before April 15, but in only 11 of 69 fields (16 per cent) planted after April 15. Differences in environmental conditions during growth of the crops are the probable cause. Early planted carrots undergo cold weather, and sometimes heavy rainfall, whereas carrots planted after April 1 grow during warmer weather and without much rainfall, if any. Early planted carrots usually require six months to harvest, whereas crops planted in April usually reach harvest size in about four months. Serious scab is usually "ring" type in early plantings, but "ring" and "punctate" types occur together in later plantings with punctate scab predominating in some cases.

TABLE 1

TIME OF DEVELOPMENT OF RING AND PUNCTATE SCAB

\begin{tabular}{l|c|c|c}
\hline \multirow{2}{*}{ Trial } & $\begin{array}{c}\text { Days since } \\
\text { planting }\end{array}$ & \multicolumn{2}{|c}{ Per cent of roots affected } \\
\cline { 3 - 4 } & & Punctate scab & Ring scab \\
\hline & 85 & 0.0 & 2.5 \\
No. 1 & 116 & 0.0 & 10.0 \\
(Planted Nov. 22) & 149 & 2.5 & 15.0 \\
& 186 & 8.0 & 29.0 \\
\hline & 78 & 2.8 & 0,0 \\
No. 2 & 111 & 35.0 & 0.0 \\
(Planted Jan. 24) & 135 & 77.2 & 0.0 \\
\hline
\end{tabular}

\section{Scab Development with Time After Planting}

Carrots were taken from fields at various dates during the growing period to determine when the greatest percentage of roots developed moderate to severe scab (table 1).

Ring scab developed somewhat earlier than did punctate scab, but the greatest increase in roots affected by both types occurred during the 30 days preceding harvest-the 149th to 186th day after planting. The data were similar in a field that developed a high percentage of punctate but very little ring seab (Trial No. 2, table 1).

\section{Effect of Crop Rotation on Scab Incidence and Severity}

Although rotation of land to other crops sometimes appears to reduce the severity of scab in a subsequent carrot crop, there is great variability in the results. The apparent effect may be due to some unknown factor other than rotation.

In some instances scab has occurred the first time a field was planted to carrots; other fields remained free of scab though planted to carrots for fifteen consecutive years or more. In some instances scab severity was greatly reduced after rotation with other crops for three or four years. However, fields not rotated have produced badly scabbed crops one year, and not the next. In such cases, the scabby crop was usually grown during winter and spring, and the scab-free crop during the summer. 


\section{Effect of Nitrogen Fertilization on Root Scabbing and Splitting}

Several field trials have been made with different rates of nitrogen from several fertilizer materials to determine their effect on the incidence and severity of scab. Sidedress applications were made to carrots about two months before harvest, and data on root scabbing and splitting were recorded just before harvest. Table 2 presents data from a trial of this type. Scab was more severe on roots that received nitrogen applications, but scabbing was increased more by lower rates than by higher rates, except with ammonium sulfate, which had the opposite effect.

TABLE 2

EFFECT ON PUNCTATE SCAB AND ROOT SPLITTING (FIELD

TRIAI,) OF NITROGENOUS FERTILIZERS APPLIED AS SIDEDRESSING*

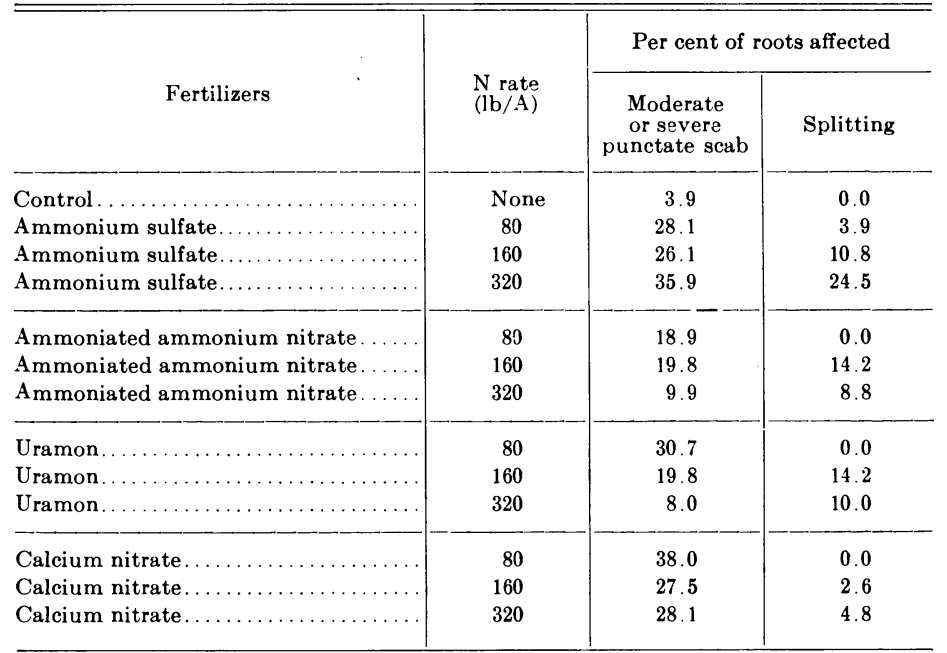

* No ring-type scab occurred in this trial.

The materials most toxic to plants-ammoniated ammonium nitrate ( 40 per cent $\mathrm{N}$ ) and Uramon-apparently do not increase scab by direct injury of the roots. If they did, the amount of scab should increase in proportion to the amount of the materials applied. It appears that there may be a certain level of nitrogen that is optimum for scab development, but that plant injury from excessive quantities of toxic nitrogen materials reduces scab incidence.

All of the nitrogenous materials increased the percentage of split roots, but calcium nitrate was not as effective as the other materials.

Nitrogen fertilizers that contain free ammonia, such as ammoniated ammonium nitrate or aqueous ammonia, were tested in several additional field trials. Table 3 shows the data from one of these trials. Applied at very high rates, these materials caused a large percentage of the roots to split lengthwise. In addition, large numbers of small rifts occurred over the root surface, 
somewhat similar in appearance to punctate scab but differing in that no overgrowth occurred to elevate the surfaces of the lesions (fig. 1E).

The reason for increased root splitting from heavy applications of nitrogenous fertilizers is not known, but it occurred consistently in all trials.

\section{Effect of Minor Element Foliage Sprays}

Solutions of ferrous sulfate, manganese sulfate, zinc sulfate, copper sulfate, and boric acid containing $500 \mathrm{ppm}$ of the respective metal cations were sprayed onto the leaves of carrots growing in a field where scab was expected. In one treatment, all of the materials were applied together in a combination spray. The carrots were sprayed three times, at approximately monthly intervals, and readings for scab were made at harvest. All were as badly scabbed as the untreated controls, with no apparent differences among the treatments.

TABLE 3

EFFECT ON RIFTING, SPLITTING, AND PRONGING OF AMMONIATED AMMONIUM NITRATE APPLIED AS SIDEDRESSING

\begin{tabular}{|c|c|c|c|}
\hline \multirow[b]{2}{*}{$\mathrm{N}(\mathrm{lb} / \mathrm{A})$} & \multicolumn{3}{|c|}{ Per cent of roots affected } \\
\hline & $\begin{array}{l}\text { Moderate } \\
\text { or severe } \\
\text { rifting }\end{array}$ & Pronging & Splitting \\
\hline Control (no treatment). & 0.5 & 1.5 & 1.0 \\
\hline $40 \ldots \ldots \ldots \ldots \ldots$ & 0.0 & 1.0 & 0.5 \\
\hline 80 & 0.0 & 1.3 & 11.4 \\
\hline 160. & 0.5 & 2.0 & 12.5 \\
\hline 320. & 10.1 & 2.7 & 34.0 \\
\hline 640 . & 51.0 & 2.7 & 71.7 \\
\hline
\end{tabular}

\section{Salt-solution Drenches of Roots Growing in Steam-sterilized and Unsterilized Field Soil}

The soils in which scab occurs in California usually contain large amounts of soluble salts. To determine whether a sudden increase in salt concentration in the root zone would influence the prevalence and severity of scab, the following experiment was conducted: soil from a field that had produced a badly scabbed crop during the previous growing season was placed in 12 inch-deep boxes in the greenhouse at Davis. Half of the boxes of soil were steam-sterilized (3 $\mathrm{hr}$ at $10 \mathrm{lb} \mathrm{psi}$ ) and half were not. The Improved Long Imperator variety of carrot was planted in all boxes. After three months, when the roots were about $1 / 2$ inch in diameter at the crown, one box each of sterilized and unsterilized soil was drenched by pouring over the soil surface 5 gallons of 1 per cent solution of $\mathrm{NaNO}_{3}, \mathrm{CaNO}_{3}$, and $\mathrm{NaCl}$, respectively. One month later the roots in all boxes were harvested, washed, and rated for scab severity: Healthy $=0$, slight $s c a b=1$, moderate $s c a b=3$, and severe scab $=5$. A scab index was calculated for each treatment by the formula:

Sum of scab rating $\times$ number of roots in the class

Total number of roots in the treatment 
The data (table 4) show some scab in all treatments. The outstanding and consistent difference was a greater amount of scab on roots in the unsterilized soil. None of the salt drenches appreciably affected the amount or severity of scab.

\section{Steam Sterilization and Chemical Treatment of Soil}

Since scab was markedly reduced in the steam-sterilized soil, samples of the same soil were treated with several chemicals and compared with steamsterilized ( $3 \mathrm{hr}$ at $10 \mathrm{lb}$ psi) and unsterilized nontreated field soil. The chemicals used were: CBP 55 (55 per cent 1-chloro-3-bromopropene), Telone (undiluted technical dichloropropenes), Chloropicrin (trichloronitromethane), Vapam 4S (4 lb/gal concentrate of sodium $N$-methyl dithiocarbamate di-

TABLE 4

EFFECT ON PREVALENCE AND SEVERITY OF SCAB OF 1 PER CENT SALT SOLUTION DRENCHES IN STEAM-STERILIZED AND FIELD SOIL

\begin{tabular}{|c|c|c|c|c|c|c|c|}
\hline \multirow{2}{*}{ Salt } & \multirow{2}{*}{ Soil } & \multirow{2}{*}{$\begin{array}{l}\text { Number } \\
\text { roots }\end{array}$} & \multicolumn{4}{|c|}{ Number in each rating } & \multirow{2}{*}{$\begin{array}{l}\text { Scab } \\
\text { index }\end{array}$} \\
\hline & & & None & Slight & Mod. & Severe & \\
\hline \multirow[t]{2}{*}{$\mathrm{NaNO}_{3}$} & Sterilized.... & 69 & 58 & 5 & 3 & 3 & 0.48 \\
\hline & Unsterilized. & 50 & 24 & 6 & 9 & 11 & 1.75 \\
\hline \multirow[t]{2}{*}{$\mathrm{CaNO}_{3}$} & Sterilized.... & 59 & 57 & 2 & 0 & 0 & 0.34 \\
\hline & Unsterilized. . & 58 & 23 & 20 & 13 & 2 & 1.19 \\
\hline \multirow[t]{2}{*}{$\mathrm{NaCl}$} & Sterilized . . . & 60 & 55 & 3 & 2 & 0 & 0.15 \\
\hline & Unsterilized . . . . . . . . . . . . . . . & 48 & 16 & 24 & 5 & 3 & 0.93 \\
\hline \multirow[t]{2}{*}{ None } & Sterilized $\ldots \ldots \ldots \ldots \ldots \ldots \ldots \ldots$ & 52 & 44 & 7 & 1 & 0 & 0.19 \\
\hline & Unsterilized . . . . . . . . . . . . . . & 51 & 10 & 27 & 12 & 2 & 1.63 \\
\hline
\end{tabular}

hydrate), and Mylone (85 per cent wettable powder of 3,5-dimethyltetrahydro-1, 3, 5-2H-thiadiazine-2-thione). The rates listed in table 5 are based on applications 6 inches deep. Mylone was mixed thoroughly with the soil by hand, the other chemicals were injected. The treated soils were immediately sprinkled with water, covered with tar-coated paper, and left undisturbed for 10 days. The soil was then uncovered, turned with a trowel every other day, and allowed to aerate for two weeks.

The variously treated soils were all planted at the same time with Improved Long Imperator carrot seed. The plants were allowed to grow four months and then were harvested and rated for scab, as previously. Results are presented in table 5. As in the previous experiment, steam sterilization markedly reduced the prevalence and severity of scab. Reductions from Mylone, Chloropicrin, and Vapam also were striking. At the rates used, CBP 55 and Telone did not reduce scab, and CBP might have actually increased it, though probably not significantly. The small lateral roots of plants in untreated field soil and in soils treated with CBP 55 and Telone appeared unhealthy: a large percentage had a yellow or yellowish-brown discoloration. In contrast, the rootlets of plants in treatments that reduced scab were much whiter and healthier in appearance. Much Rhizoctonia solani was present on the surface of untreated roots, and mycelium of a vescicular-arbuscular type 
TABLE 5

EFFECT ON SEVERITY AND PREVALENCE OF SCAB OF STEAM STERILIZATION AND CHEMICAL TREATMENT OF SOIL

\begin{tabular}{|c|c|c|c|c|c|c|c|c|}
\hline \multirow{2}{*}{ Material } & \multirow{2}{*}{ Rate/A } & \multirow{2}{*}{$\underset{\text { tion }}{\text { Replica- }}$} & \multirow{2}{*}{$\begin{array}{c}\text { Number } \\
\text { roots } \\
\text { rated }\end{array}$} & \multicolumn{4}{|c|}{ Number in each rating } & \multirow{2}{*}{$\begin{array}{l}\text { Scab } \\
\text { index }\end{array}$} \\
\hline & & & & None & Slight & Mod. & Severe & \\
\hline CBP $55 \ldots \ldots \ldots \ldots$ & $10 \mathrm{lb}$ & $\begin{array}{l}1 \\
2\end{array}$ & $\begin{array}{l}69 \\
55\end{array}$ & $\begin{array}{r}11 \\
0\end{array}$ & $\begin{array}{l}46 \\
39\end{array}$ & $\begin{array}{r}8 \\
12\end{array}$ & $\begin{array}{l}4 \\
4\end{array}$ & $\begin{array}{l}1.3 \\
1.7\end{array}$ \\
\hline CBP 55. & $30 \mathrm{lb}$ & $\begin{array}{l}1 \\
2\end{array}$ & $\begin{array}{l}70 \\
65\end{array}$ & $\begin{array}{r}5 \\
15\end{array}$ & $\begin{array}{l}27 \\
27\end{array}$ & $\begin{array}{l}29 \\
17\end{array}$ & $\begin{array}{l}9 \\
6\end{array}$ & $\begin{array}{l}2.3 \\
1.7\end{array}$ \\
\hline Mylone $85 \mathrm{~W} \ldots$ & $150 \mathrm{lb}$ & $\begin{array}{l}1 \\
2\end{array}$ & $\begin{array}{l}71 \\
77\end{array}$ & $\begin{array}{l}71 \\
71\end{array}$ & $\begin{array}{l}0 \\
6\end{array}$ & $\begin{array}{l}0 \\
0\end{array}$ & $\begin{array}{l}0 \\
0\end{array}$ & $\begin{array}{l}0.0 \\
0.1\end{array}$ \\
\hline Mylone $85 \mathrm{~W} .$. & $300 \mathrm{lb}$ & $\begin{array}{l}1 \\
2\end{array}$ & $\begin{array}{l}60 \\
70\end{array}$ & $\begin{array}{l}60 \\
70\end{array}$ & $\begin{array}{l}5 \\
3\end{array}$ & $\begin{array}{l}0 \\
0\end{array}$ & $\begin{array}{l}0 \\
0\end{array}$ & $\begin{array}{l}0.1 \\
0.0\end{array}$ \\
\hline Telone.... & $70 \mathrm{gal}$ & $\begin{array}{l}1 \\
2\end{array}$ & $\begin{array}{l}42 \\
65\end{array}$ & $\begin{array}{r}5 \\
24\end{array}$ & $\begin{array}{l}28 \\
33\end{array}$ & $\begin{array}{l}9 \\
6\end{array}$ & $\begin{array}{l}0 \\
2\end{array}$ & $\begin{array}{l}1.3 \\
0.8\end{array}$ \\
\hline Telone........... & $140 \mathrm{gal}$ & $\begin{array}{l}1 \\
2\end{array}$ & $\begin{array}{l}55 \\
53\end{array}$ & $\begin{array}{l}4 \\
8\end{array}$ & $\begin{array}{l}48 \\
39\end{array}$ & $\begin{array}{l}2 \\
6\end{array}$ & $\begin{array}{l}1 \\
0\end{array}$ & $\begin{array}{l}1.1 \\
1.1\end{array}$ \\
\hline Chloropicrin.... & $200 \mathrm{lb}$ & $\begin{array}{l}1 \\
2\end{array}$ & $\begin{array}{l}76 \\
77\end{array}$ & $\begin{array}{l}58 \\
73\end{array}$ & $\begin{array}{r}18 \\
4\end{array}$ & $\begin{array}{l}0 \\
0\end{array}$ & $\begin{array}{l}0 \\
0\end{array}$ & $\begin{array}{l}0.2 \\
0.1\end{array}$ \\
\hline Chloropicrin.... & $400 \mathrm{lb}$ & $\begin{array}{l}1 \\
2\end{array}$ & $\begin{array}{l}58 \\
76\end{array}$ & $\begin{array}{l}58 \\
76\end{array}$ & $\begin{array}{l}0 \\
0\end{array}$ & $\begin{array}{l}0 \\
0\end{array}$ & $\begin{array}{l}0 \\
0\end{array}$ & $\begin{array}{l}0.0 \\
0.0\end{array}$ \\
\hline Vapam 4S.. & $1 \mathrm{qt}^{*}$ & $\begin{array}{l}1 \\
2\end{array}$ & $\begin{array}{l}58 \\
60\end{array}$ & $\begin{array}{l}53 \\
56\end{array}$ & $\begin{array}{l}5 \\
4\end{array}$ & $\begin{array}{l}\mathbf{0} \\
\mathbf{0}\end{array}$ & $\begin{array}{l}0 \\
0\end{array}$ & $\begin{array}{l}0.1 \\
0.1\end{array}$ \\
\hline Vapam 4S.. & $2 \mathrm{qt}^{*}$ & $\begin{array}{l}1 \\
2\end{array}$ & $\begin{array}{l}39 \\
34\end{array}$ & $\begin{array}{l}38 \\
33\end{array}$ & $\begin{array}{l}1 \\
1\end{array}$ & $\begin{array}{l}\mathbf{0} \\
0\end{array}$ & $\begin{array}{l}0 \\
0\end{array}$ & $\begin{array}{l}0.0 \\
0.0\end{array}$ \\
\hline Steam sterilized .......... & & $\begin{array}{l}1 \\
2\end{array}$ & $\begin{array}{l}62 \\
64\end{array}$ & $\begin{array}{l}62 \\
62\end{array}$ & $\begin{array}{l}0 \\
2\end{array}$ & $\begin{array}{l}0 \\
0\end{array}$ & $\begin{array}{l}0 \\
0\end{array}$ & $\begin{array}{l}0.0 \\
0.0\end{array}$ \\
\hline Field soil (unsterilized).. & & $\begin{array}{l}1 \\
2\end{array}$ & $\begin{array}{l}50 \\
58\end{array}$ & $\begin{array}{l}26 \\
23\end{array}$ & $\begin{array}{l}24 \\
35\end{array}$ & $\begin{array}{r}0 \\
15\end{array}$ & $\begin{array}{l}0 \\
0\end{array}$ & $\begin{array}{l}0.5 \\
1.4\end{array}$ \\
\hline
\end{tabular}

* Per 100 sq. ft.

of fungus similar to Rhizophagus was abundant within the rootlets. Inoculation experiments with Rhizoctonia solani from scabby carrot roots have never increased scab, but the effect of Rhizophagus on carrots has not been tested.

\section{Scab Susceptibility of Several Carrot Varieties}

Plots have been put out several times to compare the susceptibility to scab of various carrot varieties. However, only one such plot was in a field where heavy scab developed. Samples of roots of each variety were dug, washed, and rated for scab. Data from this trial are presented in table 6 . There was a great difference among varieties in the amount of punctate and ring scab. Some were very susceptible to both, some more susceptible to ring scab, and others to punctate scab. All varieties showed some scabbing, but one variety, Top Weight, an Australian variety selected for high tolerance to motley 
TABLE 6

PERCENTAGE OF SCABBED AND SPLIT ROOTS

IN DIFFERENT VARIETIES

\begin{tabular}{|c|c|c|c|}
\hline \multirow{2}{*}{ Variety } & \multicolumn{2}{|c|}{$\begin{array}{l}\text { Per cent affected moderately } \\
\text { or severely }\end{array}$} & \multirow{2}{*}{ Per cent split } \\
\hline & Punctate scab & Ring scab & \\
\hline Kurenella Intermediate................ & 24.6 & 3.5 & 5.26 \\
\hline Supreme Half Long.................. & 15.5 & 12.7 & 2.82 \\
\hline French Forcing $\ldots \ldots \ldots \ldots \ldots \ldots \ldots$ & 20.0 & 25.3 & 14.67 \\
\hline Streamliner........ & 2.2 & 26.7 & 0.0 \\
\hline Oxhart.......... & 20.8 & 41.7 & 2.08 \\
\hline Long Orange $\ldots \ldots \ldots \ldots$ & 57.7 & 7.7 & 0.0 \\
\hline Danvers Half Long............ & 11.9 & 5.1 & 0.0 \\
\hline Chantenay Red Cored.$\ldots \ldots \ldots \ldots \ldots$ & 7.1 & 19.1 & 2.38 \\
\hline Top Weight $\ldots \ldots \ldots \ldots \ldots \ldots \ldots \ldots \ldots$ & 2.2 & 0.0 & 0.0 \\
\hline Early Scarlet Horn...................... & 10.5 & 10.5 & 1.75 \\
\hline Chantella.............................. & 37.4 & 19.5 & 0.0 \\
\hline 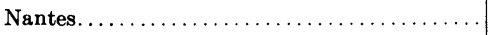 & 17.9 & 3.6 & 0.0 \\
\hline White Belgian....................... & 9.1 & 14.5 & 0.0 \\
\hline Yellow Belgian....................... & 55.6 & 7.4 & 0.0 \\
\hline Nantes Strong Top.................... & 40.8 & 14.3 & 5.55 \\
\hline 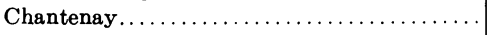 & 14.5 & 14.5 & 0.0 \\
\hline Chantenay Long Type................. & 16.1 & 16.1 & 1.78 \\
\hline 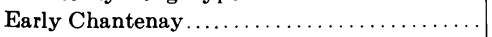 & 28.9 & 36.5 & 0.0 \\
\hline Touchon...$\ldots \ldots \ldots \ldots \ldots \ldots \ldots \ldots \ldots$ & 10.1 & 15.0 & 0.0 \\
\hline Morse's Bunching.$\ldots \ldots \ldots \ldots \ldots \ldots \ldots$ & 43.9 & 36.6 & 7.32 \\
\hline Imperator $\ldots \ldots \ldots \ldots \ldots \ldots \ldots \ldots \ldots \ldots \ldots$ & 19.6 & 21.7 & 10.87 \\
\hline Imperator Long Type.................. & 22.9 & 3.2 & 1.64 \\
\hline Imperator $\mathrm{T}-620 \ldots \ldots \ldots \ldots \ldots \ldots \ldots \ldots$ & 0.0 & 26.5 & 0.0 \\
\hline Gold Spike.......................... & 22.2 & 11.1 & 9.52 \\
\hline Average. & 21.3 & 16.4 & 2.73 \\
\hline
\end{tabular}

dwarf virus (Stubbs, 1948, 1956), had much less of both types of scab than any other variety in the test. Top Weight's root shape is similar to that of the variety Imperator, but in its present form is probably not an acceptable commercial type.

The variety listed as Imperator T-620 was derived by selection of healthy roots from a badly scabbed field. It is as susceptible as the Imperator variety to ring scab, but appears less susceptible to punctate scab.

The results of this test show that carrot varieties differ markedly in scab susceptibility, indicating that control may be achieved by the development of resistant varieties. Several sister lines of Imperator T-620 are now being tested, but a breeding program should be initiated with Top Weight or other as yet undiscovered varieties used as resistant parents.

\section{Discussion}

The etiology of carrot scab is not clearly defined. A disease of complex symptomatology, it apparently is influenced by the genotype of the individual plant as well as by many factors of the environment. Its occurrence in severe form on some roots grown in steam-sterilized soil from seed treated with heat and mercuric chloride strongly indicates that the basic cause is nonparasitic. 
However, the authors have observed several instances in which rotation with other crops or steam or chemical sterilization of the soil has greatly reduced the prevalence and severity of the disease, which suggests the influence of a biological factor or factors in its development. The failure of repeated attempts to isolate from scab lesions, organisms that are capable of causing or increasing the severity of scab, indicates that previous reports of bacteria (Ark and Gardner, 1944) and Fusarium (Ramsey, 1937; Ramsey and Wiant, 1941) causing the disease are of doubtful accuracy.

The association of scab lesions with ruptured and abnormally enlarged oil ducts, and the arrangement of punctate lesions in a line on which the oil ducts are occluded, indicate that environmental factors favoring the production and accumulation of oil also favor scab. Unknown factors that cause the deep-seated disruption of tissues of the root are probably involved, but much more study of this phase of the disease is needed.

\section{Summary}

A critical study of the morphology and etiology of carrot root seab showed that the symptomatology is quite variable and that various environmental factors influence its occurrence and development. The nature of the causal agent or agents was not definitely determined. Attack by some fungi may induce somewhat similar symptoms, but the major factors involved in the disease appear to be nonparasitic. The close association of oil ducts, either broken and/or enlarged, and the proliferation of oil-infused and surrounding tissues, appear to be major factors in producing the disease. Disease incidence depends largely on the genotype of the host and its interaction with the environment.

\section{ACKNOWLEDGMENTS}

The authors are indebted to Dr. Louis K. Mann for preparation of the slides on pathological anatomy; to Mrs. Margery P. Mann, who prepared the illustrations; and to Dr. Thomas A. Shalla, who made the electron photomicrograph in figure 3.

This study was partially supported by a grant from the Grower-Shipper Vegetable Association, Salinas, California.

\section{LITERATURE CITED}

ARK, P.A., AND M. W. GARDNER

1942. Root scab of carrot caused by Phytomonas carotae. (Abst.) Phytopathology 32: 826.

1944. Carrot bacterial blight as it affects the roots. Phytopathology 34:416-20.

ESAU, KATHERINE

1940. Developmental anatomy of the fleshy storage organ of Daucus carota. Hilgardia $13(5): 175-226$.

GROGAN, R. G., AND J. B. KENDRICK, SR.

1952. Carrot root scab-A disease complex. (Abst.) Phytopathology 42:9-10.

Grogan, R. G., AND W. C. SNYDER

1952. The occurrence and pathological effects of Stemphylium radicinum on carrot in California. Phytopathology 42:215-18.

KENDRICK, J. B.

1934. Bacterial blight of carrot. J. Agr. Research 49:493-510. 


\section{Leyendecker, P. J., ANd R. M. Nakayama}

1957. 1956 plant disease summary for New Mexico. Plant Disease Reptr. 41:53-54.

RAMSEY, G. B.

1937. Fruit and vegetable diseases on the Chicago market in 1936. Plant Disease Reptr. Suppl. 101, pp. 81-96.

RAMSEX, G. B., AND J. S. Wiant

1941. Market diseases of fruits and vegetables. Asparagus, onions, beans, peas, carrots, celery and related vegetables. U. S. Dept. Agr. Misc. Pub. 440, 70 p.

StubBs, L. L.

1948. A new virus disease of carrots: its transmission, host range, and control. Australian Jour. Sci. Res. Series B 1, pp. 303-32.

1956. Motley dwarf virus disease of carrot in California. Plant Disease Reptr. 40:76364. 

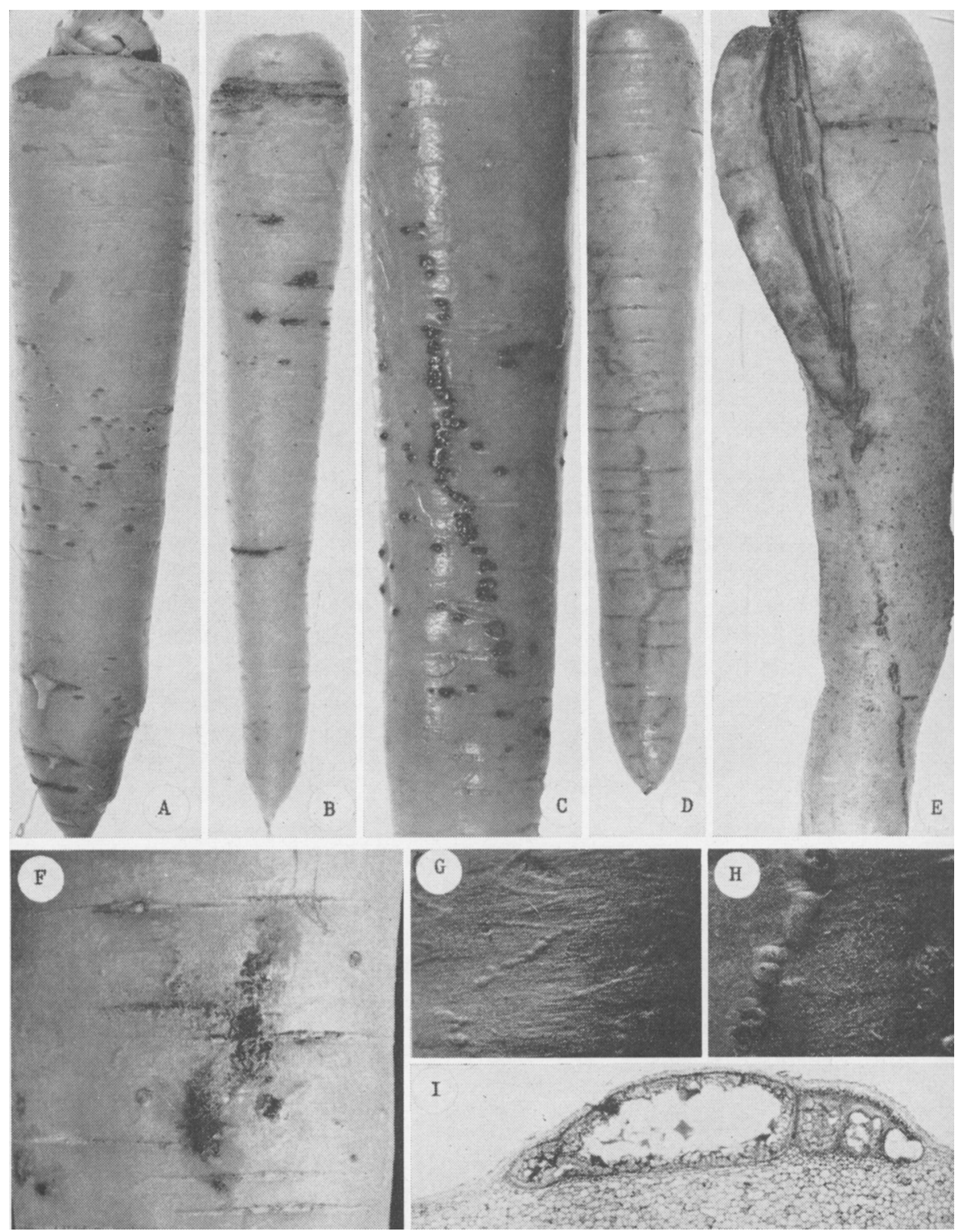

Fig. 1. Symptoms of carrot root scab: A) Raised lesions with white borders. B) Typical punctate and ring-type lesions on the same root. C) Orientation of raised punctate-type scab lesions in a row; there was a similar row on the opposite side of the root. D) Line on surface of root caused by superficial rifting of periderm. This line has the same relation to the root anatomy as the line of lesions in Figure 1C. E) Splitting and minute rifts in periderm induced by applying ammoniated ammonium nitrate solution. F) Surface of scabby root showing enlarged blisters on the periderm, some of which have broken and allowed oil-soaking of the periderm surface. G) Enlarged surface view showing wavy line of oil ducts; note that periderm is intact. $\mathrm{H}$ ) Enlarged raised ducts on root surface, two with breaks in surface and two with intact surface. I) Cross section through greatly enlarged oil duct. Note that overgrowth cells have partially occluded the duct. ( $\times 18$. 


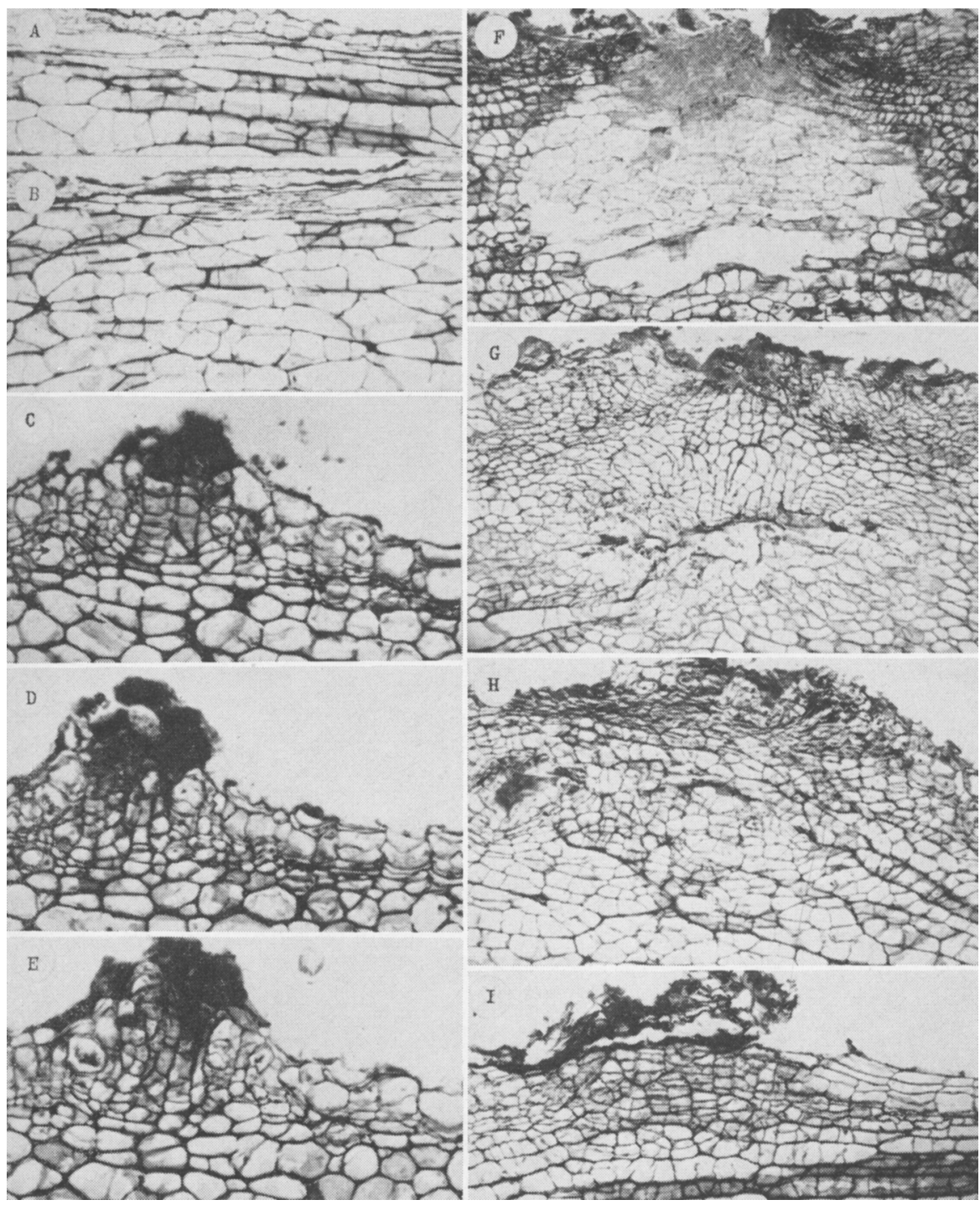

Fig. 2. Pathological anatomy of scab lesions: A) Cross section through incipient "greasy" lesion associated with the rupture of an oil duct paralleling the circumference of the root. Note oil-coated and slightly collapsed periderm area on right side of the section. $(\times 86$.$) B) Lesion similar to that in A, but associated with a duct paralleling the long$ axis of the root. ( $\times 86.) \mathrm{C}, \mathrm{D}, \mathrm{E})$ Serial section through a raised lesion oriented in a vertical line as illustrated in Figure 1C. Note that the large distinct oil duct in $2 \mathrm{C}$ is much smaller in $2 \mathrm{D}$ which is $30 \mu$ toward the center of the lesion. In $2 \mathrm{E}$, which is approximately through the center of the lesion, the duct is no longer evident; apparently it has been occluded in this area, or was never open. $(\times 154$.$) F) Large eavity in tissue below a scab lesion.$ The cavity is open to the exterior via a hole at the top and is only partially filled with overgrowth tissue. $(\times 60$.$) G) Large raised lesion that apparently originated from a cavity$ connected with an enlarged oil duct running in through the left side of the section. $(x 74$. $)$ $\mathrm{H}$ ) Large raised lesion that apparently originated from two separate cavities now filled with overgrowth cells. $(\times 80$. $)$ I) Slightly raised lesion in which oil-infused superficial tissue is being sloughed. Note the increased cell division in the pericyclic area, just below the level of the periderm. $(\times 92$. 
[Vol. 31, No. 3
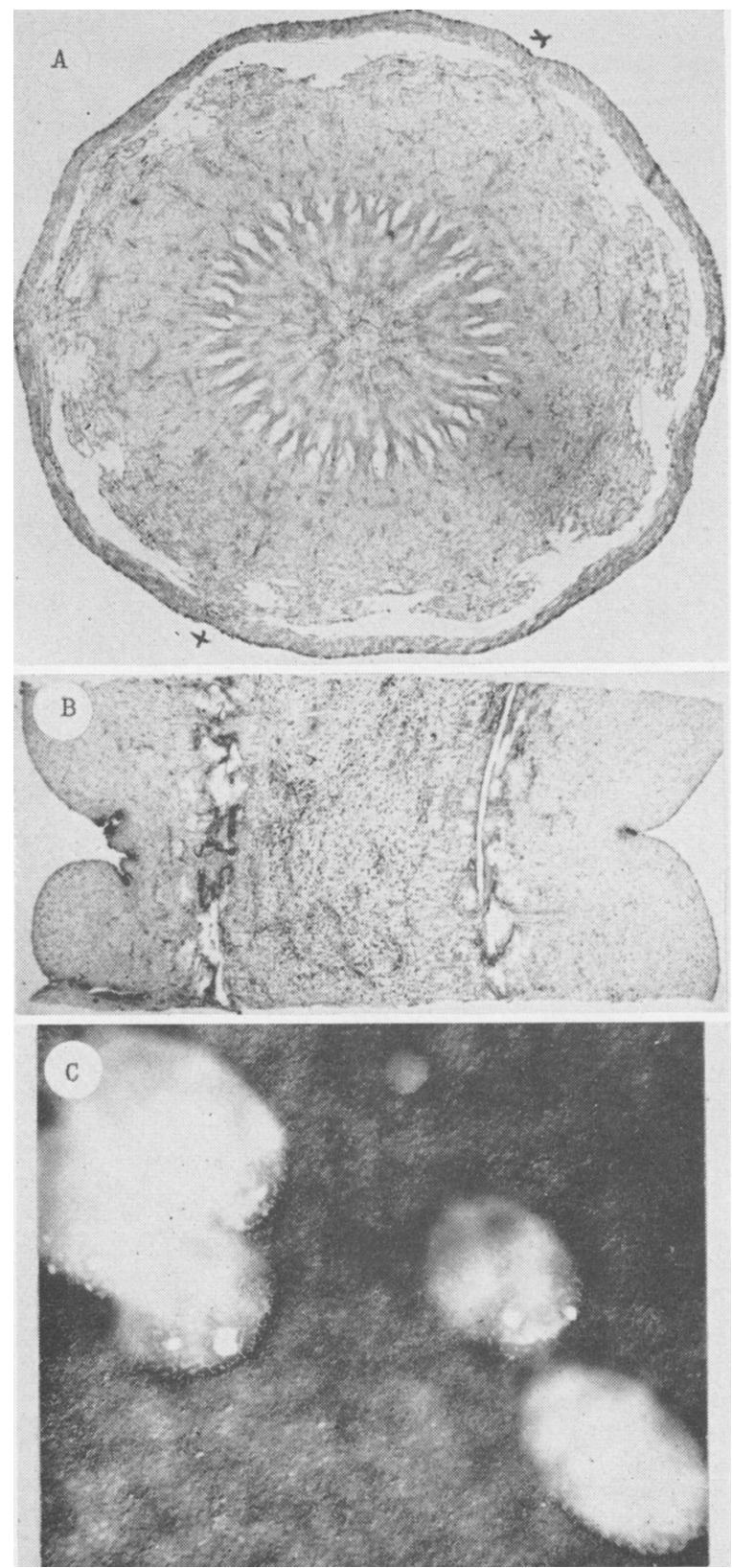

Fig. 3. Abnormalities associated with root scab: A) Cross section of small root showing separation of pericycle-periderm from the phloem, and rifts in the phloem adjacent to the cambium. $(\times 8$.$) B) Longitudinal median section through constricted area of a large$ root. Note cavities in phloem and cambium areas. C) Electron photomicrograph of particles of the white material that is exuded on the surface of fresh scab lesions. $(\times 18,600$. $)$ 
The journal Hilgardia is published at irregular intervals, in volumes of about 600 pages. The number of issues per volume varies.

Subscriptions are not sold. The periodical is sent as published only to libraries, or to institutions in foreign countries having publications to offer in exchange.

You may obtain a single copy of any issue free, as long as the supply lasts; please request by volume and issue number from:

\author{
Agricultural Publications \\ 207 University Hall \\ 2200 University Avenue \\ Berkeley 4, California
}

The limit to nonresidents of California is 10 separate issues on a single order. A list of the issues still available will be sent on request.

In our publications it is sometimes convenient to use trade names of products or equipment rather than scientific identifications. In so doing it is unavoidable in some cases that similar products which are on the market under other trade names may not be cited. No endorsement of named products is intended nor is criticism implied of similar products which are not mentioned. 
).

\section{(i)}

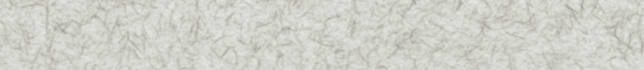

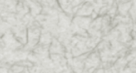

$$
\text { (2) }
$$

$$
\text { (1) }
$$

